REPRODUCTION

\title{
The ethics of using genetic engineering for sex selection
}

\author{
S Matthew Liao
}

J Med Ethics 2005;31:116-118. doi: 10.1136/jme.2003.005983

It is quite likely that parents will soon be able to use genetic engineering to select the sex of their child by directly manipulating the sex of an embryo. Some might think that this method would be a more ethical method of sex selection than present technologies such as preimplantation genetic diagnosis (PGD) because, unlike PGD, it does not need to create and destroy "wrong gendered" embryos. This paper argues that those who object to present technologies on the grounds that the embryo is a person are unlikely to be persuaded by this proposal, though for different reasons.

$\mathrm{T}$ here has been intense debate regarding whether it is ethical to use new reproductive technologies for the purpose of selecting the sex of one's child. Those against it have argued that sex selection is akin to "playing God", by interfering with the natural process of reproduction. It is also seen as harmful to children, because it treats them as a means to one's whims; ${ }^{1}$ and harmful to women because, in some countries, there is a bias in favour of having male offspring and sex selection can contribute to this bias. ${ }^{23}$ In response to these charges, advocates of sex selection have argued that sex selection can be used for good reasons such as family balancing ${ }^{4}$ and avoiding transmission of genetic disorders; that it need not treat children as mere means as long as one loves them; that it need not harm women, as an unbalanced sex ratio can increase the influence of the rarer sex and reduce population growth; ${ }^{56}$ and that allowing sex selection is protecting procreative autonomy-something we value in a liberal society. ${ }^{7-9}$

Historically, sex selection has been practiced more or less successfully and in a number of ways. The Greeks, for example, thought that tying off the left testicle would produce a male because the male determining sperm were derived from the right testicle. The Jewish tradition held the view that "When the woman emits her semen before the man, the child will be a boy. Otherwise, it will be a girl." ${ }^{10}$ Various other methods based on the positioning and timing of the intercourse or special diets have also been proposed. ${ }^{11}$ For example, some believe that superficial penetration and face to face intercourse are more likely to produce a female. Others believe that foods high in sodium and potassium such as bananas, cherries, grapes, oranges, peaches, melons, broad beans, sprouts, celery, tomatoes, or sweetcorn tend to favour a male.

I shall not enter into the debate here regarding whether sex selection is generally permissible. It seems to me though that if someone wants to eat more bananas so that she would be more likely to have a son, there would be little ethical objection against her doing so. However, even if sex selection were generally ethically permissible, it does not follow that all methods of sex selection are ethically permissible. An obvious example is infanticide. Parents can certainly use this method to have children of the desired sex, but it is clearly not ethical. Hence, it is important to evaluate the ethics of new reproductive technologies on a case by case basis.
A number of such new technologies have been employed in recent years. The most widely discussed one is preimplantation genetic diagnosis (PGD), because it can be $100 \%$ effective. ${ }^{12-14}$ PGD was developed for patients who were at risk of having children with serious genetic disorders such as haemophilia. ${ }^{15}$ In the case of sex selection, it works as follows:

1. A woman is given medicine (gonadotropins) so that she would superovulate-that is, produce many eggs.

2. Once the eggs are mature (as determined by ultrasound scans), these eggs are collected.

3. The eggs are then fertilised in the in vitro fertilisation lab.

4. On the third day (when the healthy embryos divide to form eight cell embryos), these embryos are biopsied to determine their sex (and whether they have genetic diseases).

5. The normal embryo with the desired sex is then transferred into the uterus.

6. The other embryos are typically discarded.

As one can see, PGD can be 100\% effective, because the embryo is implanted only after its sex has been determined. For this reason, many are attracted to employing this method of sex selection.

However, a number of people object to this method on the grounds that it is akin to infanticide, which is also $100 \%$ effective, but quite obviously morally wrong. The reason is that they believe that an embryo is a person. In ethics, "persons" is shorthand for those beings to which we owe the weightiest moral obligations; they are often also called rightholders. Persons typically have a right to life, which means that they have at least some immunity against attack by others. They also have a right to autonomy, which means that they should be the authors of their own lives, and that they should be free to pursue what they regard as a good life, as long as they do not interfere with other persons' pursuit. Persons may also have a right to aid in certain circumstances. For example, if a person is drowning and it would cost me little effort to save this person, then I have an obligation to save the person. If embryos are persons, then in effect, PGD is creating a number of persons and destroying the "wrong gendered" persons.

The concern that PGD destroys persons is valid of course only if one regards an embryo as being a person. Many people do not. Indeed, a number of writers have defended PGD as a viable, ethical option for sex selection, supposing that the embryo is not a person. ${ }^{16}{ }^{17}$ Also, if instead of destroying the leftover embryos, these embryos are donated to other couples and brought to term, then the concern that PGD destroys embryos would largely be gone. It is not my purpose here to evaluate the ethics of PGD or to discuss the moral status of the embryo. Here I would like to consider another possibility,

Abbreviations: PGD, preimplantation genetic diagnosis. 
that one can avoid the issue about the moral status of the embryo altogether by using genetic engineering for sex selection. Advances in genetic technologies have meant that it is possible directly to alter a person's genes. If one could alter the sex genes of an embryo directly, this may obviate the need to create and destroy "wrong gendered" embryos.

In this paper, I would like to examine this hypothetical proposal. I shall argue that those who regard embryos as persons-let us call them "embryoists" - are unlikely to be impressed by this method, but for different reasons.

\section{THE ETHICS OF USING GENETIC ENGINEERING FOR SEX SELECTION}

As far as I know, no one has tried to use genetic engineering for sex selection. But given the rapid advances in the human genome project and genetic engineering generally, it seems that its possibility is not remote. ${ }^{18}$ How would this method work? Genetic engineering involves putting the desired "new" gene into a little virus-like organism, which is then allowed to get into the target cell and insert the new gene into the cell along with the "old" genes. There are two kinds of genetic engineering: somatic and germline. Somatic engineering targets the genes in specific organs and tissues of the body of a single existing person without affecting genes in their eggs or sperm. Germline engineering targets the genes in eggs, sperm, or very early embryos. A way of using genetic engineering for sex selection is then to put the "gendered" genes of the desired sex in a virus-like organism and use germline engineering to alter the sex of an embryo.

Assuming that one can perform such modification safely, would this method be more ethical? Although this method would avoid the problem of killing persons, embryoists are not going to be persuaded. The reason is that if an embryo is a person, then it could be argued that this method interferes with a person's autonomy without the person's consent. The idea here is as follows: an implication of a person's having a right to autonomy is that if someone wants to do something that may interfere with that person's pursuit of a good life, that the person's consent is typically necessary. There are circumstances when such consent might not be necessaryfor example, in cases where the benefit to the person would be really great, such as when their life would be saved. ${ }^{19}$ Indeed, suppose a person is unconscious and needs a certain operation in order to survive, a doctor may justifiably perform such an operation without the person's consent, on the grounds that it is a life saving medical operation. But these life saving situations aside, consent is typically necessary.

Essentially, changing the sex of the embryo through genetic engineering is performing a sex change operation on the embryo. Typically, to perform such an identity altering operation on a person, the person's consent is required..$^{201}$ The reason is that such an operation is typically not a life saving one. Indeed, a doctor would not be permitted to perform a sex change operation without consent. And even if someone were not able to consent, it is generally agreed that others cannot consent on their behalf for such non-health related treatments.

If one believes that the embryo is a person and therefore has a right to autonomy, then, as with the case above, it seems that changing the sex of the embryo would also require the embryo's consent. As the embryo is not able to consent, but given that this operation is not a life-saving medical operation, it seems that others should not be permitted to consent on the embryo's behalf.

THE POWER AND LIMITS OF PARENTAL AUTONOMY Someone might point out though that parents often justifiably act on their children's behalf without their children's consent, at least in non-health related cases. ${ }^{22}$
For example, parents often decide how their children should be educated, what clothes their children should wear, whether their children should play the piano or football, and so on, without their children's consent. As we grant parents much power in shaping the social identity of a child, why should parents not be permitted to shape the genetic identity of a child-in particular, to alter the sex of an embryo without the embryo's consent?

One thing to note is that parents actually do not have total power over the social identity of their children, whereas they would in the case of the genetic identity, assuming that genetic engineering is feasible. Indeed, from very early on, infants exhibit preferences for food, clothing, sleep schedules, and so on, and have means to resist parental preferences, should their own preferences conflict with those of the parents. One cannot say the same of embryos. Secondly, it seems that one needs to distinguish between non-health related decisions affecting a person that are reversible versus those that are irreversible. When parents make non-health related, lifestyle decisions regarding how their children should be educated, how they should dress, and so on, these are all decisions that are reversible-a child can later, in adulthood, choose alternatives. As such, these decisions limit but do not deprive a child of his autonomy. But non-health related, irreversible decisions made on behalf of a child would deprive that child of his autonomy, because a life course will have been chosen for him without his being able to alter it. If we believe in the value of autonomy, then it seems that such non-health related irreversible decisions made on behalf of another without the other's consent should not be permitted. ${ }^{23}{ }^{24}$

In fact, one can use this principle to explain a recent ruling by the Constitutional Court of Colombia. ${ }^{25}$ The Court was asked to determine whether biological parents have the authority to subject their intersexed children (children born with both male and female genitalia) to surgery. The Court ruled that biological parents do not have such authority, by arguing that biological parents should put the child's best interest ahead of their own fears and concerns about sexual ambiguity. The principle I proposed above can explain this ruling because this kind of surgery is typically non-health related and irreversible. Indeed, many intersexed adults have argued that the decision to have surgery should be left to the individual when old enough to make the decision. ${ }^{26-34}$

Before concluding, I would like to consider whether genetic engineering would be more ethical if the embryo was not considered to be a person. I argue that it would not be, if we agree that changing a person's sex without that person's consent is a violation of their autonomy. This is because even though a person does not yet exist (the embryo is not yet a person), genetic engineering affects an identifiable individual. In particular, the embryo would have developed to become a person of a particular sex except for one's act, which has caused this embryo to become a person of a different sex. As an adult, this person could complain that he or she could have been different had the modification not taken place. The fact that the harm to the embryo takes place only at a future date does not change the fact that an act of harm-in this case, a violation of autonomy-has been committed against an identifiable individual. Compare this with the following example: suppose I planted a bomb now that will explode 100 years from now and kill a certain number of people. I will have committed a harm now to these people, even though they do not yet exist.

Here it might be interesting to point out the same argument is not applicable to PGD. The reason is that PGD works by selecting embryos of a particular sex for implantation rather than by modifying particular embryos. Given this, the selected embryo in PGD that is brought to existence 
cannot complain about being harmed as an embryo, because if a different embryo had been selected, he or she would not have existed. ${ }^{35-37}$ The issues of consent and autonomy do not arise because such selection is the same as when a child is conceived in the normal way where the issues of consent and autonomy also do not arise. The embryo in genetic engineering, on the other hand, can complain about being harmed, as it could have existed in a different state, except for the modification done to it. In this respect, this may yet be another reason for preferring PGD over genetic engineering in cases of sex selection.

\section{CONCLUSION}

In this paper, I have examined the proposal that using genetic engineering to alter the sex of an embryo might be more ethical than PGD, and argued that embryoists are not likely to be persuaded that it can because, although this method does not destroy the embryo, it violates the consent of the embryo. I considered the response that we typically grant parents enormous power over a child's social identity and therefore we should grant them parallel power over a child's genetic identity; and concluded that we should not, and in fact do not, grant parents such powers when "non-health related irreversible" decisions are involved. I further argued that these arguments apply even if we believe that the embryo is not a person. Given this, what should embryoists who want to select the sex of their children do at present? If they believe that embryos are indeed persons, the only ethical options for them would be the more unreliable methods such as sperm sorting.

\section{ACKNOWLEDGEMENTS}

I would like to thank Julian Savulescu, Wibke Gruetjen, and the two referees for their comments on earlier drafts of this paper.

Correspondence to: S Matthew Liao, $624 \mathrm{~N}$ Broadway, Floor 3, Phoebe R Berman Bioethics Institute, Johns Hopkins University, Baltimore, MD 21205, USA; sliao@jhsph.edu

Received 23 July 2003

In revised form 18 January 2004

Accepted for publication 19 January 2004

\section{REFERENCES}

1 Benagiano G, Bianchi P. Sex preselection: an aid to couples or a threat to humanity? Hum Reprod 1999; 14:868-70.

2 Baird P. Individual interests, societal interests, and reproductive technologies. Perspect Biol Med 1996:40:440-51.

3 Wertz DC, Fletcher JC. Ethics and Human Genetics: A Cross Cultural Perspective. Heidelberg: Springer-Verlag, 1989; Benagiano and Bianchi, Sex Preselection, op, cit.

4 Pennings G. Family balancing as a morally acceptable application of sex selection. Hum Reprod 1996; 11:2339-43.
5 Liu P, Rose GA. Sex Selection: The right way forward. Hum Reprod $1996 ; 11: 2343-45$

6 Sureau G. Gender selection: a crime against humanity or the exercise of a fundamental right? Hum Reprod 1999;14:867-8.

7 Savelescu J. Sex selection: the case for. Med J Aust 1999:171:373-75.

8 Harris J. 'Goodbye Dolly?' the ethics of human cloning. J Med Ethics 1997;23:353-60.

9 Ethics Committee of the American Society for Reproductive Medicine. Preconception gender selection for nonmedical reasons. Fertil Steril 2001:75:861-4.

10 Shushan A, Schenker J. Prenatal sex determination and selection. Hum Reprod 1993;8:1545-9.

11 Carson SA. Sex selection: the ultimate in family planning. Fertil Steril 1988:50:16-19.

12 Fugger EF. Clinical experience with flow cytometric separation of human Xand Y-chromosome bearing sperm. Theriogeneology 1999;52:1435-40.

13 Fugger EF, Black SH, Keyvanfar K, et al. Births of normal daughters after Microsort sperm separation and intrauterine insemination, in-vitro fertilization, or intracytoplasmic sperm injection. Hum Reprod 1998;13:2367-70

14 Robertson JA. Preconception gender selection. Am J Bioeth 2001;1:2-9.

15 Malpani A, Malpani A, Modi D. Preimplantation sex selection for family balancing in India. Hum Reprod 2002;17:11-12.

16 Robertson JA. Extending preimplantation genetic diagnosis: the ethical debate. Hum Reprod 2003;18:465-71.

17 Dahl E. Ethical issues in new uses of preimplantation genetic diagnosis: should parents be allowed to use preimplantation genetic diagnosis to choose the sexual orientation of their children? Hum Reprod 2003;18:1368-9.

18 Hood L. The human genome project-launch pad for human genetic engineering. In: Stock G, Campbell J, eds. Engineering the human germline. New York: Oxford University Press, 2000:83.

19 House of Lords' Re F (Mental Patient: Sterilisation) [1990] 2 AC 1.

20 Beauchamp TL, Childress JF. Principles of biomedical ethics, 4th edition. New York: Oxford University Press, 1994.

21 Faden RR, Beauchamp TL. A history and theory of informed consent. New York: Oxford University Press, 1986.

22 House of Lords' Re T (A Minor) (Wardship: Medical Treatment) (1996) 35 BMLR 63

23 Feinberg J. The child's right to an open future. In Freedom and fulfilment: philosophical essays 76-97, Princeton: Princeton University Press, 1992.

24 Davis DS. Genetic dilemmas and the child's right to an open future. Hastings Cent Rep 1997:27:7-15.

25 SU-337/99, 12 May 1999 and T-551/99 2 August 1999. See also http:// www.isna.org/colombia/pr.html (accessed 22 November 2004).

26 Chase C. Affronting reason. In: Atkins D, eds. Looking queer: body image and gay identity in lesbian, bisexual, gay, and transgender communities. New York: Harrington Park Press, 1998:205-19.

27 Chase C. Special issue on intersexuality. In: Chrysalis: The Journal of Transgressive Gender Identities 1997/1998;2.

28 Crouch R. Betwixt and between: the past and future of intersexuality. J Clin Ethics 1998;9:372-84

29 Dreger AD. Hermaphrodites and the medical invention of sex. Cambridge: Harvard University Press, 1998.

30 Dreger AD. Ethical issues in the medical treatment of intersexuality and 'ambiguous sex'. Hastings Cent Rep 1998;28:14-24.

31 Dreger AD. Intersex in the age of ethics. Hagerstown, MD: University Publishing Group, 1999

32 Herdt G, ed. Third sex, third gender: beyond sexual dimorphism in culture and history. New York: Zone Books, 1996.

33 Kessler $\mathbf{S}$. The medical construction of gender: case management of intersexed infants. Signs: Journal for Women in Culture and Society 1990;16:3-26.

34 Preves SE. Intersex and identity: the contested self. New Brunswick, NJ: Rutgers University Press, 2003.

35 Parfit D. Reasons and persons. Oxford: Oxford University Press, 1984:358-9.

36 Hanser M. Harming future people. Philos Public Aff 1990;19:47-70.

37 Woodward J. The non-identity problem. Ethics 1986;96:804-31. 